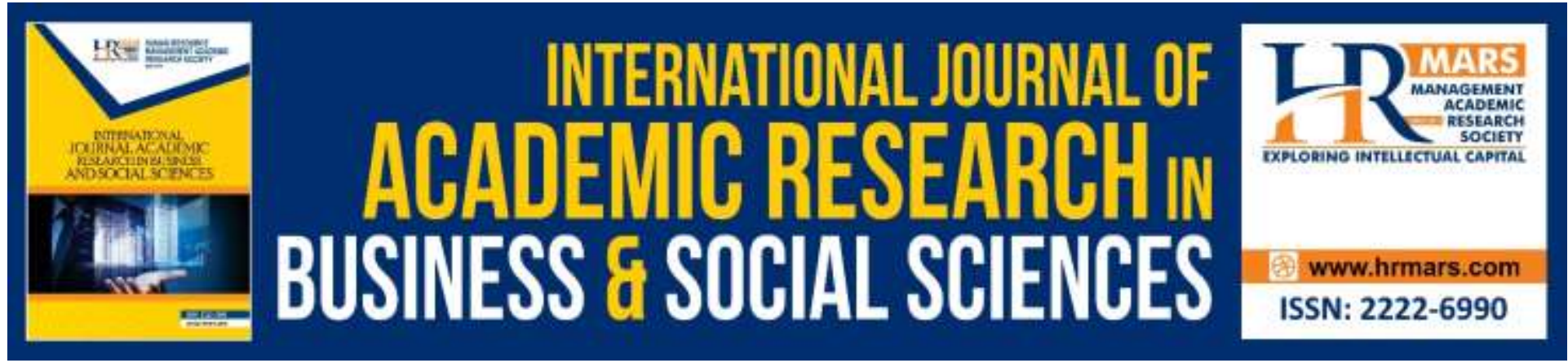

\title{
A Corpus-based Genre Analysis: Moves in Introductory Paragraph of Argumentative Writing
}

\section{Anita a/p Kanestion and Manvender Kaur a/p Sarjit Singh}

To Link this Article: http://dx.doi.org/10.6007/IJARBSS/v9-i7/6182

DOI: $10.6007 /$ IJARBSS/v9-i7/6182

Received: 24 May 2019, Revised: 23 June 2019, Accepted: 30 June 2019

Published Online: 12 July 2019

In-Text Citation: (Kanestion \& Singh, 2019)

To Cite this Article: Kanestion, A. a/p, \& Singh, M. K. a/p S. (2019). A Corpus-based Genre Analysis: Moves in Introductory Paragraph of Argumentative Writing. International Journal of Academic Research in Business and Social Sciences, 9(7), 821-831.

Copyright: (C) 2019 The Author(s)

Published by Human Resource Management Academic Research Society (www.hrmars.com)

This article is published under the Creative Commons Attribution (CC BY 4.0) license. Anyone may reproduce, distribute, translate and create derivative works of this article (for both commercial and non-commercial purposes), subject to full attribution to the original publication and authors. The full terms of this license may be seen

at: http://creativecommons.org/licences/by/4.0/legalcode

Vol. 9, No. 7, 2019, Pg. 821 - 831

Full Terms \& Conditions of access and use can be found at http://hrmars.com/index.php/pages/detail/publication-ethics 


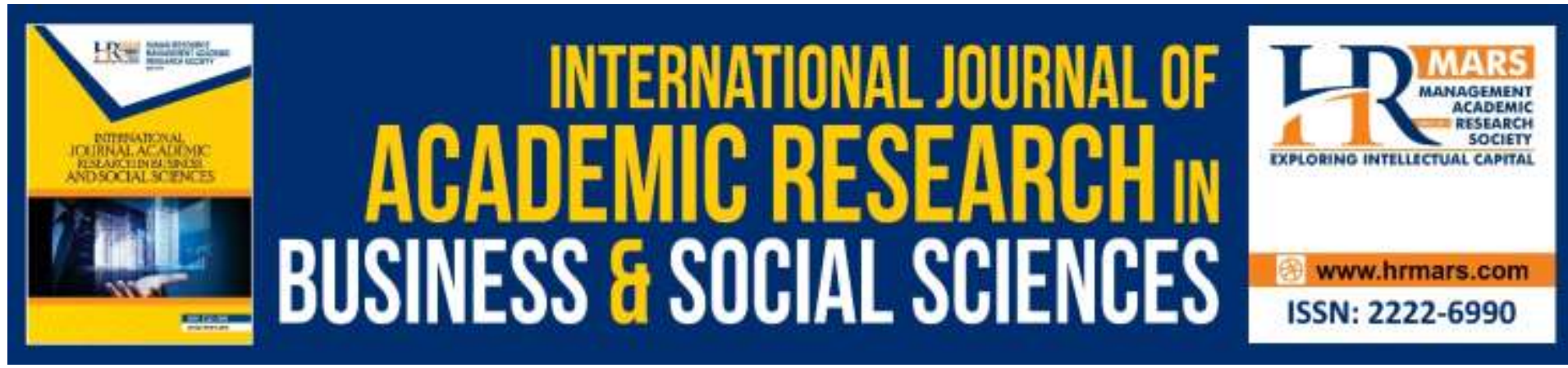

\title{
A Corpus-based Genre Analysis: Moves in Introductory Paragraph of Argumentative Writing
}

\author{
Anita a/p Kanestion and Manvender Kaur a/p Sarjit Singh \\ School of Languages, Civilisation and Philosophy (SCLP), Universiti Utara Malaysia, Sintok, \\ Kedah,Malaysia
}

\begin{abstract}
In Malaysia, the framework of genre analysis has been widely used for analyzing undergraduates and postgraduates target discourse, particularly research articles and theses. Conversely, limited studies have been conducted on argumentative essays produced by preuniversity students who are sitting for Malaysian University English Test (MUET). This study is aimed at analyzing the introductory paragraphs of 14 argumentative essays using move analysis. For this purpose, a compiled representative corpus of argumentative essays was used as a main instrument to examine the rhetorical moves in the compiled essays. As a corpus-based study, the identification of rhetorical moves was examined via a computerassisted corpus analysis (CACA). The findings of this preliminary study revealed that there were 3 moves and 9 steps identified in the compiled introductory paragraphs. The pedagogical implications based on the results of the study were proposed and the ideas for future research were discussed.

Keywords: Rhetorical Moves, Genre Analysis Framework, Malaysian University English Test (MUET), Argumentative Essay, Computer-Assisted Corpus Analysis (CACA).
\end{abstract}

\section{Introduction}

Writing is considered as one of the most challenging tasks for English as Second Language (ESL) learners to become proficient in (David, Thang, \& Azman, 2015; Elashri, 2013; Ka-kandee \& Kaur, 2015; Kanestion, Sarjit Singh, Shamsudin, 2017; Komara, 2018; Yunus \& Chien, 2016). This is due to the fact that written abilities amongst non-native speakers are not acquired naturally, but learned and practiced through experience (Grape and Kaplan, 1999). In order to be able to comprehend and produce a satisfactory level of writing proficiency, linguistic competence alone is inadequate, the rhetorical structure of a text should also be considered by the second language writers. Bhatia (1993) has inferred that the rhetorical structure exists in the macro-organization of writing, which involves a few stages of organization of information. In short, rhetorical structure can be referred as a formal structure a text which is accepted or known by its discourse community.

Acknowledging the fact that the structural rhetorical organization of a text varies across language and culture, Kaplan (1966), has introduced a notion as contrastive rhetoric 
which believes writing is a reflection of cultural thought patterns. In this field of knowledge, contrastive rhetoricians are concerned with understanding and analyzing the rhetorical structure of both L1 and L2 written discourse. In relation to the critiques, researchers claim that it only provides a greater understanding about the cultural differences (Matsuda, 1997; Connor \& Mauranen, 1999). Though studies are abounding under the umbrella of contrastive rhetoric, especially in ESL context, yet the need for the students to learn the rhetorical structure still exists (Reza \& Atena, 2013) and it is important to note that knowing the rhetorical structure in English and other languages or cultures probably would only help the learners to comprehend the differences and similarities exist in written text; however, this would not encourage the ESL learners to explore and understand their own writing strategies. Evidently, contrastive rhetoric has yet to provide a structure that could be used as a framework in the ESL language classes, particularly in Malaysia.

Since the presence of Swales' (1990) model of Create A Research Space (CARS), there has been a great interest in analysing different types of texts within the area of English for Specific Purposes (ESP), including academic and professional texts, namely the introduction of research articles (Swales, 1990; Ina, Aizan \& Hashimah, 2015); abstracts (Tseng, 2011; San \& Tan, 2012; Chalak \& Norouzi, 2013; Abarghooeinezhad \& Simrin, 2015); book preface (Abdollahzadeh \& Salarvand, 2013; Ali, Muhammad \& Asim, 2015); book reviews (Nodoushan \& Montazeran, 2012), proposals and theses (Jalilifar, Firuzmand \& Roshani, 2011; Choe \& Hwang, 2014), research articles (Maswana, Kanamaru \& Tajino, 2015; Kanoksilaphatam, 2003); laboratory reports (Parkinson, 2017) and work procedures of engineers (Manvender, 2014). Researchers in these studies have focused on the study of the rhetorical structure of various texts as it is very much common in the field of genre analysis. Consequently, such analyses have helped, especially the novice writers to adopt the rhetorical structure of the target genres in academic and professional settings.

Like other types of academic writing (theses, research articles, proposals, and problem statement) argumentative essay is considered as a genre, its own because it receives an accepted rhetorical structure which is assumed by the discourse community. Albeit, the notion of rhetorical structure is initiated by Swales (1990) who investigates the rhetorical structure of introduction of research articles consists of several moves and steps, but at the same era, Hyland (1990) has proposed an analytical model of an argumentative essay using 65 essays of sampled non-native speakers, which consists of three stages and several moves. However, to the best of the authors' knowledge, there have been limited studies using Hyland's analytical framework (1990) in the field of genre analysis, which could be resulted from the approach used in developing the model. For instance, Imtiaz and Mahmood (2014) have adopted this model using 33 argumentative essays produced by college and university students in Pakistan at ICLE (The International Corpus of Learner English) as to explore the move structures of the essays and to identify the learners' weaknesses in writing; since the identification of the moves are subjective, the researchers fail to display the validation and reliability process thoroughly. The findings only reveal the similarities and differences with some additional new moves yet no attempt is made to propose an analytical framework of argumentative essays that could be employed widely in teaching and learning context. Methodologically, the moves are identified manually, which contradicts to the present study as the researchers are using a computer-assisted corpus analysis, for short (CACA) 
(Manvender, 2012; 2014) and to avoid subjectivity of the identified moves, validation and reliability tests are carried out.

Due to its limitation, the rhetorical structure in argumentative writing undergoes further examination and development using Swales' (1990) move analysis. A move is classified as a unit that functions within a segment of a text and this directly provides an overall purpose of the text. The functions of the moves are realized when writers employ a step or a combination of steps (Bhatia, 1993). This is evident in Chandrasegaran's (2008) work where argument practices are investigated, namely stance assertion moves, stance support moves and rhetorical use of topic knowledge in two discourse situations; online informal argument and formal argumentative essay. Nevertheless, the study has neglected the aspect of argumentative writing holistically where there are communicative goals that need to be achieved formally in education context.

It appears from the aforementioned investigations that most attention has been paid to academic writing and professional setting, yet argumentative writing amongst preuniversity students remain something of a neglected area, especially in Malaysia. Consequently, the present study tends to conduct move analysis using Swales' (1990) model, and Hyland's (1990) analytical framework as a guideline, which is hoped to be used as a framework in building teaching and learning material. Similar to other researches, which focus only on one aspect or also known as sub-genre like introduction, problem statement, discussion and conclusion, this study aims to examine the introductory paragraph of argumentative essays written by the sampled pre-university students.

\section{Research Questions}

The following research questions were framed to guide the study.

i) What are the rhetorical moves in the introductory paragraphs of the sampled argumentative essays produced by the pre-university students?

ii) What are the frequencies of the rhetorical moves used in the introductory paragraphs of argumentative essays produced by the pre-university students?

\section{Methodology \\ Participants}

Participants

The participants of this study were pre-university students from two pre-university colleges located in Perlis and Kedah. The participants were homogeneous as all of them were 18 years old at the time of data collection. Pre-university colleges were selected as the students would sit for Malaysian University English Test (MUET) in November every year. MUET is a proficiency test which is conducted widely in the country prior to tertiary education. At pre-university level, it is compulsory for the students to sit for the test as it is a mandatory requirement for university intake. 


\section{Instruments}

\section{Corpus}

Prior to actual MUET, the pre-university students were given a past year question to write an argumentative essay in the classroom. Two raters who had the experience of teaching and marking for more than 10 years independently scored the essays. The inter-rater reliability was 0.73. For the purpose of this study, a genre-specific corpus was compiled using a purposive sampling method, thus a total number of 14 Band 5 argumentative essays composed by the pre-university students in the respective colleges in Malaysia were selected and compiled as a representative learner corpus.

\section{Swales (1990) Model and Hyland's (1990) Analytical Framework}

In the present analysis, Swales' (1990) CARS model, together with Hyland's (1990), was employed to guide the researchers in identifying the moves and steps used in the argumentative essays. In his analysis, there were 3 moves involved in producing an introduction of research articles. Therefore, to fit the objectives of the study, the researchers aimed to investigate the introductory paragraph or the first stage of an argumentative essay, which is Thesis according to Hyland's (1990) analytical framework. The reason for adopting Swales' (1990) model is that it is comprehensive and extensively used as a framework of analysis in various disciplines and genres. In another spectrum, Hyland's (1990) framework was employed to complement the analysis process as the framework was developed using the second language learners (L2) in a second language setting, alike Malaysia. However, limited studies had utilized this framework under the frame of genre analysis probably due to its reliability.

Table 1. Swales's (1990) CARS model for research articles' Introduction

\begin{tabular}{l|l}
\hline Moves & Steps \\
\hline Move 1 Establishing a centrality & $\begin{array}{l}\text { Step 1: Claiming centrality, and/or } \\
\text { Step 2: Making topic generalization, and/or } \\
\text { Step 3: Reviewing previous research; }\end{array}$ \\
\hline Move 2 Establishing a niche, & $\begin{array}{l}\text { Step 1A: Counter claiming, or } \\
\text { Step 1B: Indicating a gap, or }\end{array}$ \\
& $\begin{array}{l}\text { Step 1C: Question arising, or } \\
\text { Step 1D: Continuing tradition; }\end{array}$ \\
\hline Move 3 Occupying a niche & $\begin{array}{l}\text { Step 1A: Outlining purposes, or } \\
\text { Step 1B: Announcing present research, } \\
\text { Step 2: Announcing primary findings, }\end{array}$ \\
& Step 3: Indicating research article structure. \\
\hline
\end{tabular}


INTERNATIONAL JOURNAL OF ACADEMIC RESEARCH IN BUSINESS AND SOCIAL SCIENCES

Vol. 9, No. 7, July, 2019, E-ISSN: 2222-6990 @ 2019 HRMARS

Table 2. Hyland's (1990) analytical framework

\begin{tabular}{l|l}
\hline Stage & Moves \\
\hline Thesis & (Gambit) \\
Introduces the proposition to be argued & $\begin{array}{l}\text { Attention Grabber - controversial } \\
\text { statement of dramatic illusion. }\end{array}$ \\
\hline
\end{tabular}

(Information)

Presents background material for topic

contextualization.

Proposition

Furnishes a specific statement of position.

(Evaluation)

Positive gloss - brief support of proposition.

(Marker)

Introduces and /or identifies a list.

\section{Computer-Assisted Corpus Analysis (CACA)}

The students' written argumentative essays were compiled into a learner corpus consisting of a developed individual corpus which was named Band 5AE1. This became the raw corpus of the study. After collecting the students' written texts, they were converted to plain texts and saved in a new folder. Then, the researchers set a new code for each written text such as MUETB5_AE1 which refer to the Band 5 essay produced by the students No.1. These texts were again saved in Notepad++ 6.9.2 (2016), which is free online software, to tag the moves manually in the written texts. Using Swales' (1990) and Hyland's (1990) framework, as an initial guide, the corpus was move-tagged manually (Figure 1) and a list of moves used by the students were developed by the researchers. Subsequently, AntConc version 3.4.3w (2014) was also used to compute the frequencies of moves in the compiled argumentative essays. To avoid the word count errors to occur, each move was placed in the angle brackets $<>$.

$<$ Move 2a> "There are no secrets to success. It is the result of preparation, hard work and learning from failure"-Colin Powell

$<$ Move $\mathbf{2 b}>$ Success is deservingly rewarded to those who work hard, perspire and keep trying. $<$ Move $\mathbf{2 b}>$ Of the many people that graced their presence on the face of the earth all shared a similar attribute - hard work. <Move 2a> The great Nelson Mandela did not achieve his mission overnight. <Move 2a> He suffered an arduous battle in his conquest for freedom. $<$ Move 2a> Mahatma Gandhi pursued his non-violent battle with the British in search of freedom. <Move 2a> And imagine if Sir Isaac Newton had not tried repeatedly to create his light bulb. $<$ Move $\mathbf{2} \mathbf{b}>$ The world today would definitely not have become if not for these people who preserved till the very

end. <Move 3a> In the same manner, albeit we may not attain success in such a drastic level, we all can take heed that success is determined by one's own perseverance and hard work.

Figure 1. Manual Move-tagged MUETB5_AE1

Inter-coder reliability 


\section{Inter-coder Reliability}

The objectivity in the analysis was maintained as the moves in the introductory paragraphs were identified by a rater and the researcher. Unlike Hyland's (1990) framework, the intercoder reliability assessment was selected as the best tool and the agreement between the coders was measured using Cohen's Kappa value (k). To evaluate the reliability of coding, an English lecturer, a subject matter expert and also an experienced examiner from a preuniversity college, was initially trained everything related to the moves. Then he was given 7 out of 14 samples to check and code based on the coding system identified by the researcher of this study. If there were discrepancies in distinguishing a particular move in a sentence, both the coder and the researchers would discuss and agree on a common solution. Several discussions were made on the move analysis model proposed by the researcher. Since the Cohen's kappa value was .731, the strength of agreement was at good (Altman, 1991; Qin \& Karabacak, 2010). Therefore, the coding system was reliable and valid to be used extensively in this study.

\section{Results and Discussion}

Albeit, move analysis has been widely used in analyzing academic writing at tertiary level as a tool to enhance student's writing skills (Cotos, Huffman, \& Link, 2015; Imtiaz, 2014), the researcher in this study believe that the use of move analysis has also benefited the investigation on how the written argumentative texts are structured by the pre-university students which have not been paid too much attention in language classrooms, particularly in Malaysia. Answering to the first research question, the following moves were determined in the argumentative essays written by the pre-university students.

Table 3. List of Moves and Steps in the Introductory Paragraphs of Argumentative Essays

\begin{tabular}{|c|c|c|}
\hline Stage & Moves & Steps \\
\hline \multirow{3}{*}{ Introduction } & $\begin{array}{l}\text { Move 1: Establishing an } \\
\text { issue } \\
\text { (Providing background } \\
\text { information to } \\
\text { contextualise the topic } \\
\text { or/and issue to grab the } \\
\text { reader's attention) }\end{array}$ & $\begin{array}{l}\text { 1a. Defining the key word(s) or the topic } \\
\text { 1b. Describing the key word(s) or the topic } \\
\text { 1c. Describing an issue related to the topic or } \\
\text { providing example(s) to explain the issue } \\
\text { 1d. Providing driving question or pertinent } \\
\text { question(s) to contextualise the topic }\end{array}$ \\
\hline & $\begin{array}{l}\text { Move 2: Citing an expert or } \\
\text { a survey } \\
\text { (Providing evidence(s) to } \\
\text { support the issue) }\end{array}$ & $\begin{array}{l}\text { 2a. Providing an expert's opinion (quotes), } \\
\text { prominent figure's contribution or a survey } \\
\text { to reinforce the writer's position } \\
2 \text { b. Expressing agreement or disagreement } \\
\text { with the opinion or contribution }\end{array}$ \\
\hline & $\begin{array}{l}\text { Move 3: Announcing } \\
\text { position }\end{array}$ & $\begin{array}{l}\text { 3a. Stating the writer's position or a stand } \\
\text { 3b.Providing a thesis statement by indicating } \\
\text { the main ideas (at least 3) to support the } \\
\text { writer's position }\end{array}$ \\
\hline
\end{tabular}


Contrary to Hyland's (1990) framework, in this study, the first stage is identified as Introduction by the researchers as in Malaysia, the Thesis stage is frequently known as an introductory paragraph (Kanestion \& Sarjit Singh \& Shamsudin, 2017). This is probably due to the fact that English speakers tend to open their discourse with a thesis directly contrary to the non-native speakers, particularly Asians as they prefer to use an orderly presentation in which the thesis is delayed by some sufficient background information (Misyana \& Kamisah, 2012). Thus, the researchers have made some modification in relation to the first stage to cater the students' and teachers' needs.

These moves shape the main outline of the students' introductory paragraphs of argumentative essays and they are realized as well as shaped by steps. For instance, Move 1 Establishing an issue is realized based on the combination of four steps (Table 3). Similar to Kanestion, Sarjit Singh \& Shamsudin (2017), Move 1: Establishing an issue is used to provide the reader(s) some background information related to the topic(s) together with some issues to grab the reader's attention, and in this study, it was shaped by four steps as compared to Hyland's (1990) which was realised by two moves; Gambit and Information.

Move 2 is all about citing an expert's opinion or a survey which is mainly to support the general statements given in Move 1 and writers express either agreement or disagreement towards the expert's opinion and justify to support the writer's position, which was mentioned in Swales' model as Reviewing previous research (Move 1, Step 3) but unseen in Hyland's framework. This move has a crucial role in judging the quality of the argumentative essay (Ka-kan-dee \& Kaur, 2015) and according to McKinley (2015), citing others' work is an important exercise in critical thinking and evidently, this move was shaped by two steps (2a and $2 \mathrm{~b}$ ). Subsequently, Move 3 , mostly used at the end of an introductory paragraph, is employed to announce the writer's position, whether the writer agrees, disagrees or being neutral with topic and provide a thesis statement, thus, the respective move was realized by two steps which are $3 a$ and $3 b$.

Using the concordance tool (AntConc 3.4.3w), the occurrences of moves in the introductory paragraphs of Band 5 argumentative essays are calculated (refer to Table 4) as to answer the second research question. 
Table 4. The occurrence of moves in introductory paragraphs of Band 5 argumentative essays

\begin{tabular}{|c|c|c|c|c|c|c|c|c|c|}
\hline \multirow[b]{2}{*}{ Essays/Moves } & \multicolumn{4}{|c|}{ Move 1} & \multicolumn{2}{|c|}{ Move 2} & \multicolumn{2}{|c|}{ Move 3} & \multirow[t]{2}{*}{ Total } \\
\hline & $1 a$ & $1 b$ & 1c & 1d & $2 a$ & $2 b$ & $3 a$ & $3 b$ & \\
\hline MUETB5_AE1 & 0 & 0 & 1 & 0 & 5 & 3 & 1 & 0 & 10 \\
\hline MUETB5_AE2 & 2 & 5 & 0 & 3 & 0 & 0 & 1 & 2 & 13 \\
\hline MUETB5_AE3 & 0 & 0 & 0 & 1 & 1 & 1 & 1 & 1 & 5 \\
\hline MUETB5_AE4 & 2 & 1 & 0 & 0 & 0 & 0 & 2 & 1 & 6 \\
\hline MUETB5_AE5 & 0 & 1 & 5 & 1 & 2 & 0 & 1 & 0 & 10 \\
\hline MUETB5_AE6 & 0 & 0 & 4 & 1 & 1 & 1 & 1 & 1 & 9 \\
\hline MUETB5_AE7 & 1 & 1 & 4 & 0 & 1 & 0 & 2 & 0 & 9 \\
\hline MUETB5_AE8 & 0 & 2 & 0 & 1 & 1 & 1 & 1 & 1 & 7 \\
\hline MUETB5_AE9 & 2 & 2 & 2 & 0 & 0 & 0 & 1 & 1 & 8 \\
\hline MUETB5_AE10 & 0 & 0 & 2 & 0 & 2 & 1 & 2 & 1 & 8 \\
\hline MUETB5_AE11 & 2 & 2 & 0 & 0 & 0 & 0 & 2 & 2 & 8 \\
\hline MUETB5_AE12 & 0 & 0 & 2 & 2 & 1 & 1 & 1 & 1 & 8 \\
\hline MUETB5_AE13 & 1 & 3 & 1 & 0 & 1 & 1 & 1 & 1 & 9 \\
\hline MUETB5_AE14 & 0 & 4 & 1 & 0 & 1 & 1 & 1 & 1 & 9 \\
\hline Total & 10 & 21 & 22 & 9 & 15 & 10 & 18 & 13 & \\
\hline
\end{tabular}

Table 4 indicates the occurrence of moves in the introductory paragraphs of Band 5 MUET argumentative essays. As highlighted in the table, Band 5 writers have the highest frequency of move for Move 1c (Describing an issue related to the topic or providing example(s) to explain the issue) with 22 occurrences and sub-corpus coded as MUETB5_AE5 recorded the most frequent user with 5 occurrences. It suggests that Band 5 writers must have had gone straight to the heart of the topic by providing some necessary background information related to the theme or topic. This is followed by Move $1 \mathrm{~b}$ (Describing the key word(s) or the topic) and Move 3a (Stating the writer's position or a stand) with 21 and 18 occurrences respectively. In contrast, Move $1 d$ reports the lowest frequency of use (9) as only 6 sub corpus are identified in providing driving or pertinent question. Meanwhile Move 1a, which is defining the key words related to the topic shows 10 occurrences. This displays that Band 5 writers have the ability to define the terms using their prior knowledge.

The occurrence of Move $2 a$ and Move $2 b$ have shown that writers are able to support their claims with solid evidences, like citing prominent figures, with 15 and 18 occurrences respectively. Move $2 a$ is marked as the most recurring move in MUETB5_AE1 with 5 occurrences. This reveals that the writer has exercised critical thinking skills by citing others' work. On the other hand, MUETB5_AE2 has the highest number of moves (13) whereas MUETB5_AE4 displays the lowest number of moves (6) as the writer only employs two moves in the introductory paragraph (Move 1 and Move 3). From the findings, it can be deduced that Move 1c, Move 1b and Move 3a are obligatory moves in the introductory paragraphs of Band 5 written argumentative essays while the remaining moves are seen as optional. 


\section{Conclusion}

By and large, the analyses reveal that having such rhetorical structure reflects the logical organization of the introductory paragraph which consecutively provides a comprehensive outline of information to the readers, who are the examiners (San \& Tan, 2012). Notwithstanding, based on the information gathered in Table 4, it is interesting to mark that there are some discrepancies in each introductory paragraph. In order to achieve its communicative purpose, Band 5 writers are found to use most of the moves and steps. It can be deduced that, Move $1 \mathrm{~b}$, Move $1 \mathrm{c}$ and Move 3a are obligatory.

It is evident that pre-university students need to be aware of the argumentative essay's structure, especially the rhetorical structure in the Band 5 introductory paragraphs of argumentative essays as majority of them had difficult time to construct and develop ideas (Ka-kan-dee \& Kaur, 2015; Yunus \& Chien, 2016) in MUET. Consequently, the familiarisation of rhetorical structure, as a framework, can ease the students writing process in producing effective introductory paragraphs. In the same vein, this framework, which is descriptive in nature, can also be employed as a scaffolding tool to maneuver the students producing their own piece of writing as it offers a platform, particularly for the students to understand their weaknesses and strengths. This corroborates with Ka-kan-dee \& Kaur (2015) and Kanestion, Sarjit Singh \& Shamsudin (2017) findings who claim that genre-based instruction would enable the students to master the writing skills as they are exposed to the important linguistic features of the genre.

However, the current study has not completely involved other sub-genres of argumentative writing, such as arguments and conclusion. Future research could be conducted using move analysis to analyse argument and conclusion stages, thus a combination of qualitative and quantitative approach with a larger corpus could be employed to give a holistic finding.

Another noteworthy contribution of this study would be in the form of the introduction of $n$ effective tool, namely the computer-assisted corpus analysis, for short CACAs who are looking for a quick and easy approach for assessing their students'

\section{Acknowledgement}

We would like to thank our colleagues from Matriculation College who provided insight and expertise that greatly assisted the research

\section{Corresponding Author}

Manvender Kaur a/p Sarjit Singh

School of Languages, Civilisation and Philosophy (SCLP), Universiti Utara Malaysia

Sintok, Malaysia

Email: manvender@uum.edu.my

\section{References}

Abarghooeinezhad, M., \& Simin, S. (2015). A structural move analysis of abstract in electronic engineering articles. International Journal of Research Studies in Language Learning, 4(4), 69-80.

Abdollahzadeh, E. \& Salarvand, H. (2013). Book Prefaces in Basic, Applied and Social Sciences: A Genre Based Study. WASJ 28(11), 1618-1626. 
Ali, S., Muhammad, Z. \& Asim, M. (2015). A Genre Analysis of Preface Sections of Textbook. Journal Education and Practice, 6(7), 58-64.

Bahtia, V.K. (1993). Analysing Genre: Language Use in Professional Settings. London: Longman.

Chandrasegaran, A. (2008). NNS students' arguments in English: Observations in formal and informal contexts. Journal of Second Language Writing, 17(4), 237-254. https://doi.org/10.1016/j.jslw.2008.04.003

Cotos, E., Huffman, S., \& Link, S. (2015). Furthering and applying move/step constructs: Technology-driven marshalling of Swalesian genre theory for EAP pedagogy. Journal of English for Academic Purposes, 19, 52-72. https://doi.org/10.1016/j.jeap.2015.05.004

David, A. R., Thang, S. M., \& Azman, H. (2015). Accommodating Low Proficiency Esl Students' Langu Age Learning Needs Through an Online Writing Support System. Journal of Social Sciences and Humanities, 1(Special Issue (1)), 118-127. https://doi.org/10.1017/CBO9781107415324.004

Elashri, I. I. E. A. E. (2013). The effect of the genre-based approach to teaching writing on the EFL al-Azhr secondary students' writing skills and their attitudes towards writing, 158.

Imtiaz, Z. (2014). Genre Analysis of Argumentative Essays of Pakistani EFL Learners. Journal of Education and Practice, 5(30), 95-101.

Ka-kan-dee, M., \& Kaur, S. (2015). Teaching Strategies Used by Thai EFL Lecturers to Teach Argumentative Writing. Procedia - Social and Behavioral Sciences (Vol. 208). Elsevier B.V. https://doi.org/10.1016/j.sbspro.2015.11.191

Kanestion, A., \& Sarjit Singh, Manvender Kaur, Shamsudin, S. (2017). Developing A Framework For Writing Skill : A Corpus-Based Analysis Of The. Sains Humanika, 9:4-2, 39-47.

McKinley, J. (2015). Critical Argument and Writer Identity: Social Constructivism as a Theoretical Framework for EFL Academic Writing. Critical Inquiry in Language Studies, 12(3), 184-207. https://doi.org/10.1080/15427587.2015.1060558

Parkinson, J. (2017). English for Speci fi c Purposes The student laboratory report genre : A genre analysis. English for Specific Purposes, 45, 1-13. https://doi.org/10.1016/j.esp.2016.08.001

Qin, J., \& Karabacak, E. (2010). The analysis of Toulmin elements in Chinese EFL university argumentative writing. System, 38(3), 444-456. https://doi.org/10.1016/j.system.2010.06.012

Tandiana, S. T., Abdullah, F., \& Komara, U. (2018). the Students' Argumentative Writing Skills. English Education and Applied Linguistics Journal, 1(1), 60-68.

Yunus, M. M., \& Chien, C. H. (2016). The Use of Mind Mapping Strategy in Malaysian University English Test (MUET) Writing. Creative Education, 07(04), 619-626. https://doi.org/10.4236/ce.2016.74064 